\title{
COMPARISON OF QUALITY CONTROL PARAMETERS OF DIAGNOSTIC X-RAY MACHINES IN GOVERNMENT, MISSION AND PRIVATE OWNED FACILITIES IN JOS, NIGERIA
}

\author{
${ }^{* 1}$ Ike-Ogbonna, M. I., ${ }^{2}$ Mangset, W. E. and ${ }^{3}$ Ike, E. E.
}

\begin{abstract}
${ }^{*}$ Department of Physics, University of Jos, Plateau State, Nigeria. Phone: 08035923954 Email: ikeogbonnaijeoma@yahoo.com ${ }^{2}$ Department of Physics, University of Jos, Plateau State, Nigeria. Phone: 08066388044 Email: edaci2001@yahoo.com ${ }^{3}$ Department of Physics, University of Jos, Plateau State, Nigeria. Phone: 08034507181 Email: eniemeka@gmail.com
\end{abstract}

\begin{abstract}
Due to the availability and frequent use of x-ray machine in the diagnoses of diseases and treatment of diseases in most of our hospitals and radio-diagnostic centers in Nigeria, the need to assess the quality control parameters and level of compliance of the x-ray machines cannot be over emphasized. The purpose of this research is to compare the result of four Quality Control test parameters of government (G1and G2), mission (M1 and M2) and private owned (P1and P2) x-ray machines of the radio-diagnostic facilities to ascertain the level of compliance among them with the set reference tolerance limits. Four Quality Control test parameters; kVp accuracy, congruence between optical and x-ray field, beam alignment and tube filtration was assessed from the measurement carried out using Gammex Radiologic kit with Gammex 330 digital kV meter, Gammex 115A half value layer set, collimator test tool model 161B and the beam alignment test tool model 162A.The result of $\mathrm{kVp}$ accuracy show that G1,G2,M2 and P1 all had values ranging from $2.30 \%-3.14 \%$ within the set tolerance limit of $\pm 5 \%$ while M1 and P2 had values above the limit. In congruence between optical and $\mathrm{x}$-ray field with tolerance limit of $\pm 2 \%$, only P2 was above limit, while in perpendicularity G2 and P2 were above the set limit of $1.5^{\circ}$. Tube filtration all the studied x-ray machines failed the test indicate absorption of excess low energy dose for patient. This research therefore reveals that the government and mission $\mathrm{x}$-ray machines have better quality control programme that the private owned.
\end{abstract}

Keywords: comparison, government, mission, private, quality control parameters, $x$-ray machines

LICENSE: This work by Open Journals Nigeria is licensed and published under the Creative Commons Attribution License 4.0 International License, which permits unrestricted use, distribution, and reproduction in any medium, provided this article is duly cited.

COPYRIGHT: The Author(s) completely retain the copyright of this published article.

OPEN ACCESS: The Author(s) approves that this article remains permanently online in the open access (OA) mode.

QA: This Article is published in line with "COPE (Committee on Publication Ethics) and PIE (Publication Integrity \& Ethics)". 


\section{INTRODUCTION}

In Nigeria, x-ray has remained the most frequently used ionizing radiation in medicine despite advances in magnetic resonance imaging and ultrasound techniques. It has maintained a key role in diagnosis of diseases, injury and in X-ray therapy (Oluwafisoye et al, 2010). In effect it is the largest man-made source of ionizing radiation to the world population for health applications (ICRP, 1991, UNSCEAR, 1993). The level of compliance with the regulatory control and radiation protection if poor will constitute in unpredictable high and low tube output voltage and beam misalignment. Which will lead to over or under exposure, poor image quality, poor diagnosis and even retakes as the case may be. This too may have strong public health implications. Xray exposures are a very significant source of medical purposes, and due to its increasing use in diagnoses, developed countries have shown an increase use of 58\% between the 2000 (United Nations, [UN], 2000) and 2008 (UN, 2010) reports of the United Nations Scientific Committee on the Effects of Atomic Radiation (UNSCEAR), of the diagnostic exposures. Computed tomography (CT) was by far the greatest contributor, accounting for $7.9 \%$ of examinations, but $47 \%$ of the dose. For the whole world population, the annual effective dose per person from medical sources is $0.62 \mathrm{mSv}$ compared with $2.4 \mathrm{mSv}$ for natural sources (IAEA, 2002).

The World Health Organization (WHO) defines a quality assurance (QA) programme in diagnostic radiology as an organized effort by the staff operating a facility to ensure that the diagnostic images produced are of sufficiently high quality so that they consistently provide adequate diagnostic information at the lowest possible cost and with the least possible exposure of the patient to radiation (WHO, 1982). Quality assurance therefore means the planned and systematic actions that provide adequate confidence that a diagnostic $\mathrm{x}$-ray facility will produce consistently high-quality images with minimum exposure of the patients and healing arts personnel. Quality assurance actions include both "Quality Control" techniques and "Quality Administration" procedures. Quality assurance programme is an essential step in the implementation of Radiation Protection Culture (RPC) (Agapi \& Efstathios, 2016).

In as much as implementation of Quality Assurance is a complex and demanding process and has to be supported by legal regulatory bodies of the country, effective QA program or radiation protection culture in diagnostic radiology enables the achievement and maintenance of obtaining radiological information of appropriate quality for the purposes of medical diagnosis, minimizing doses received by patient and medical personnel compatible with the type of clinical examination undertaken and also optimize the costs by cutting losses of time and resources (Marija, Tomislav,Ivica \& Durya, 2008). Hence, there is also growing concern in recent times on the old and fairly used $\mathrm{x}$-ray machines in our hospitals which are not under regulatory control by the Nigeria Nuclear Regulatory Authority (NNRA).The radiological medical practitioner, the medical physicist, the medical radiation technologist and the radiation protection officer all have key roles and responsibilities in implementing radiation protection in the radiology facility (ICRP, 1990).

\section{MATERIALS AND METHODS}

The assessment was carried out by comparing the following quality control parameters: $\mathrm{kVp}$ accuracy, congruence between optical and $\mathrm{x}$-ray, beam perpendicularity and tube filtration for government, mission and private owned radio diagnostic facilities. The quality control test was done for six x-ray machines using a Gammex Radiologic kit with Gammex 330 digital $\mathrm{kV}$ meter, collimator test tool model 161B, beam alignment test tool model 162A and Gammex 115A half value layer set. 


\section{DETERMINATION OF KVP ACCURACY}

(i) The $\mathrm{kV}$ meter was placed on a radiographic table on top of a grid and positioned at the centre of the beam axis with a focus field distance (FFD) of $100 \mathrm{~cm}$.

(ii) The light field was collimated and centred to fall on the $\mathrm{kV}$ meter which was placed on a grid to reduce scattered radiation.

(iii) The measurement was then done at a constant milliampere second (mAs) but gradually increasing tube potential of 50- $90 \mathrm{kV}$ for five readings.

(iv) In each case, the dosimeter was reset after the exposure and the reading were recorded.

(v) The reading obtained was used to determine the percentage error for the tube potential ( $\mathrm{kVp}$ accuracy) using the formula

$$
\mathrm{kVp} \text { accuracy }=\frac{k V p_{\text {measured- } k V p_{\text {set }}}}{k V p_{\text {set }}} \times 100 \%
$$

\section{DETERMINATION OF THE BEAM ALIGNMENT, COLLIMATION AND CONGRUENCE}

(i) The collimator test tool and beam alignment test tool were both placed directly on an intensifying screen cassette with the beam alignment tool aligned onto the centre of the collimator test tool which was a flat brass plate of rectangular shape with markings etching on its surface.

(ii) With a fixed $\mathrm{kVp}$ and $\mathrm{mAs}$.

(iii) An exposure was done on a well collimated light field.

(iv) When film was developed the marked etching, surface was seen on the radiographic film and the positions of the two steel balls.

(v) The beam alignment, congruence and collimation were then measured for each $\mathrm{x}$-ray machine.

\section{DETERMINATION OF HALF VALUE LAYER (HVL)}

(i) The half value layer was measured for each $\mathrm{x}$-ray machine at a focus field distance (FFD) of $100 \mathrm{~cm}$ and a fixed $\mathrm{kVp}$ and $\mathrm{mAs}$ which depends on the particular $\mathrm{x}$-ray machine studied.

(ii) The $\mathrm{kV}$ meter was place on a grid placed on the radiographic table.

(iii) The x-ray beam was centred on the meter and the light field was collimated to fall on the $\mathrm{kV}$ meter.

(iv) An initial measurement was done and recorded with no aluminium attenuator filter covering the light field.

(v) Subsequent readings are then taken by varying the alloy aluminium thickness from 1, 2, 3, 4 and 5mm at the same $\mathrm{kVp}$ and $\mathrm{mAs}$ by mounting each at different interval to cover the light field.

(vi) With the $\mathrm{kV}$ meter in place measuring the dose output, a deceasing value of radiation dose was measured.

(vii) The values were used to determine the HVL of each specific $\mathrm{x}$-ray machine under investigation. 


\section{RESULT AND DISCUSSION}

Table 1: Results of quality control test parameters for the studied radio diagnostic facilities

\begin{tabular}{|c|c|c|c|c|c|c|c|}
\hline $\begin{array}{l}\text { Quality } \\
\text { Control } \\
\text { parameters }\end{array}$ & $\begin{array}{l}\text { Recommended } \\
\text { tolerance limit }\end{array}$ & G1 & G2 & M1 & M2 & P1 & $\mathbf{P 2}$ \\
\hline kVp Accuracy & $\pm 5 \%$ & $3.14 \%$ & $2.64 \%$ & $9.96 \%$ & $2.30 \%$ & $2.40 \%$ & $15.94 \%$ \\
\hline Congruence & $\pm 2 \%$ & $1 \%$ & $2 \%$ & $2 \%$ & $1 \%$ & $2 \%$ & $>2 \%$ \\
\hline Perpendicularity & $1.5^{\circ}$ & $0.5^{\circ}$ & $3.0^{\circ}$ & $0.5^{\circ}$ & $1.5^{\circ}$ & $1.5^{\circ}$ & $>3^{\circ}$ \\
\hline Tube filtration & $\begin{array}{l} \pm 1.5 \mathrm{mmAl} \text { at } \\
70 \mathrm{kVp}\end{array}$ & $3.3 \mathrm{~mm}$ & $2.1 \mathrm{~mm}$ & $2.0 \mathrm{~mm}$ & $4.0 \mathrm{~mm}$ & $2.8 \mathrm{~mm}$ & $2.7 \mathrm{~mm}$ \\
\hline
\end{tabular}

Table 2: summary of the QC test performance of the studied radio diagnostic facilities

\begin{tabular}{|c|c|c|c|c|c|c|c|}
\hline $\begin{array}{l}\text { Quality } \\
\text { Control } \\
\text { parameters }\end{array}$ & $\begin{array}{l}\text { Recommended } \\
\text { tolerance limit }\end{array}$ & G1 & G2 & M1 & M2 & P1 & $\mathbf{P 2}$ \\
\hline kVp Accuracy & $\pm 5 \%$ & $\begin{array}{l}\text { Within } \\
\text { limit }\end{array}$ & $\begin{array}{l}\text { Within } \\
\text { limit }\end{array}$ & $\begin{array}{l}\text { Above } \\
\text { limit }\end{array}$ & $\begin{array}{l}\text { Within } \\
\text { limit }\end{array}$ & $\begin{array}{l}\text { Within } \\
\text { limit }\end{array}$ & $\begin{array}{l}\text { Above } \\
\text { limit }\end{array}$ \\
\hline Congruence & $\pm 2 \%$ & $\begin{array}{l}\text { Within } \\
\text { limit }\end{array}$ & $\begin{array}{l}\text { Within } \\
\text { limit }\end{array}$ & $\begin{array}{l}\text { Within } \\
\text { limit }\end{array}$ & $\begin{array}{l}\text { Within } \\
\text { limit }\end{array}$ & $\begin{array}{l}\text { Within } \\
\text { limit }\end{array}$ & $\begin{array}{l}\text { Above } \\
\text { limit }\end{array}$ \\
\hline Perpendicularity & $1.5^{\circ}$ & $\begin{array}{l}\text { Within } \\
\text { limit }\end{array}$ & $\begin{array}{l}\text { Above } \\
\text { limit }\end{array}$ & $\begin{array}{l}\text { Within } \\
\text { limit }\end{array}$ & $\begin{array}{l}\text { Within } \\
\text { limit }\end{array}$ & $\begin{array}{l}\text { Within } \\
\text { limit }\end{array}$ & $\begin{array}{l}\text { Above } \\
\text { limit }\end{array}$ \\
\hline Tube filtration & $\pm 1.5 \mathrm{~mm}$ & $\begin{array}{l}\text { Above } \\
\text { limit }\end{array}$ & $\begin{array}{l}\text { Above } \\
\text { limit }\end{array}$ & $\begin{array}{l}\text { Above } \\
\text { limit }\end{array}$ & $\begin{array}{l}\text { Above } \\
\text { limit }\end{array}$ & $\begin{array}{l}\text { Above } \\
\text { limit }\end{array}$ & $\begin{array}{l}\text { Above } \\
\text { limit }\end{array}$ \\
\hline
\end{tabular}

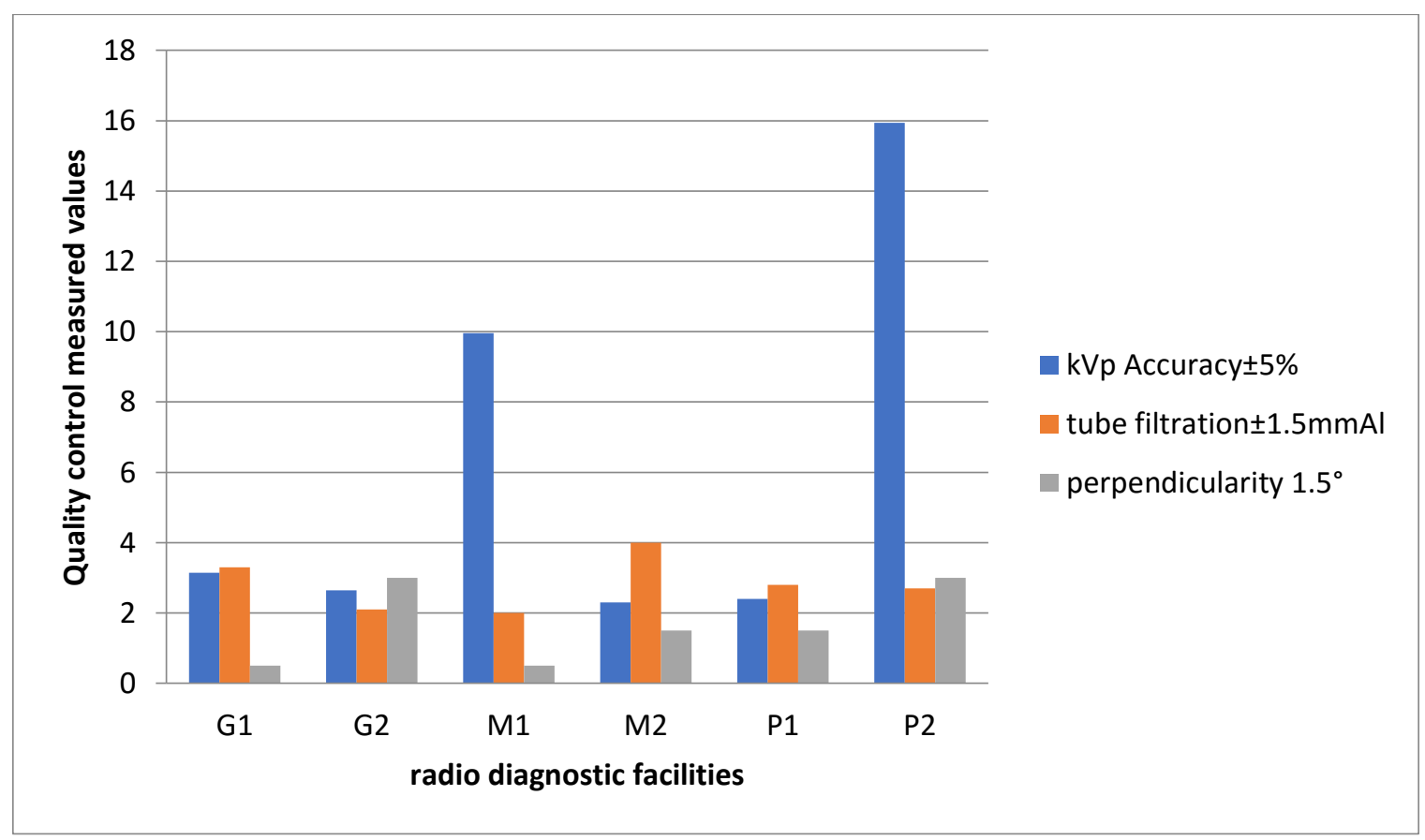

Figure 1: Representation of quality control test parameter result for the studied x-ray machines 




Figure 2: Representation of congruence of optical and x-ray field for the studied x-ray machines

Table 1 shows the result of the quality control test parameters of the six x-ray machines studied in the radio diagnostic facilities. The data shows that neither the government, mission nor private owned facilities passed all the four-quality control test carried out each one of them failed at least one test. However, on Accuracy of the $\mathrm{kV}$ settings ascertains that the $\mathrm{kV}$ selection at the control panel results in the same $\mathrm{kV}$ applied across the $\mathrm{x}$-ray tube showed high deviation from the tolerance limit of $\pm 5 \%$ for M1 and P2 as shown on table 2 and figure 1.

The variation of tube output with $\mathrm{kVp}$ was calculated using equation (1). The reason for the high deviation in $\mathrm{kVp}$ values may be as a result of the age of the $\mathrm{x}$-ray machine, variation in $\mathrm{x}$-ray generator not being set correctly upon installation or poor maintenance and also as a result of excessive power line voltage drop (Mallam et al \& Ogundare et al., 2004). It is advised that this test be formed upon acceptance and after a major system repair, then annually (IAEA \& Rehani, 1995). It is important the $\mathrm{kV}$ setting functions properly as it determines the x-ray beam quality, image contrast and has implications on the patient dose (WHO, 1982). The excess derivation between the set and measured $\mathrm{kVp}$ could reduce the image contrast and cause unnecessary and unwanted exposure (Livingstone et al \& Godfrey et al., 2006, 2015).

The result of congruence of optical and x-ray field only P2 was above the tolerance limit of $\pm 2 \%$ as shown on figure 2, this implies that there is need for maintenance check to be carried to align its light field to its collimated area since misalignment reduces diagnostic image quality and leads to exposure of non-targeted areas. It is caused by the shift in the position of the light field, reflecting mirror and anode focal spot (IAEA., 1995).

Beam perpendicularity G2, and P2 were both above the tolerance limit of $1.5^{\circ}$ with values $3.0^{\circ}$, hence there is need for manual adjustment for the $\mathrm{x}$-ray light field for it to become perpendicular to the image receptor. As alignment of the tube beam to the required area of exposure is important for a quality image contrast and improper alignment of optical and radiation field introduces distortion in the radiographic image and is likely to cause deletion of essential information for diagnosis. (Bushong., 2001). Also, in tube filtration for operating at tube potential of $70 \mathrm{kVp}$ the inherent filtration HVL should be $1.5 \mathrm{~mm} \mathrm{Al}$ (AAPM, 1989), all the studied x-ray 
machines all failed the test. Hence the advantage of added filtration to enable the effective energy approach the maximum $\mathrm{kVp}$ with elimination of all low energy doses which could add to the patient's dose was not adequate (IAEA, 1995\& 2004).

\section{CONCLUSION}

From the aim of this research, which is to compare the quality control parameters of the government, mission and private owned x-ray machines, it be observed that the government and mission facilities seen to have a betterquality control parameter than the privately owned radio diagnostic facilities. There is therefore need for the regularity authority and personnels saddled with the responsibility of maintenance to frequently and adequately carry out quality control check on the x-ray machines as at when due to prevent over exposure of patients and staff to radiation dose. Also, the government and mission facilities still need to improve on their quality control programme in order to have all the quality control parameters function effectively and efficiently. 


\section{REFERENCES}

Ploussi, A., and Efstathopoulos P.E. (2016). Importance of establishing radiation protection culture in Radiology department. World Journal of Radiology, 8(2): 142-147.dio: 10.4329/wjr. v8.i2.142

American Association of Physicists in Medicine. (1989). Protocols for the radiation safety surveys of diagnostic radiological equipment. (Report 25). New York: Author.

Bushong, S.C. (2001). Radiologic science for technologists (10th ed.). USA: CV Mosby Co. St. Lous Missouri.

Godfrey, L. D., Adeyemo, D. J. and Sadiq, U. (2015). Radiological kVp accuracy, reproducibility and consistence assessment of some hospitals in Zaria environs of Kaduna state, Nigeria. Scholars Research Library. Archives of Applied Science Research. 7(5): 27 31. Retrieved on $21^{\text {st }}$ February, 2020 from: http://scholarsresearchlibrary.com/archive.html

International Atomic Energy Agency (1995). Radiation doses in diagnostic radiology and methods for dose reduction, IAEA-TECDOC-796, Vienna: Author.

International Atomic Energy Agency (2002). Radiological protection for medical exposure to ionizing radiation, IAEA safety standards series no. Rs-g-1.5, Vienna: Author.

International Atomic Energy Agency (2004). Optimization of the radiological protection of patients undergoing radiography, fluoroscopy and computed tomography, Vienna: Author.

International Commission on Radiological Protection (1990). Recommendations of the International Commission on Radiological Protection, Publication 60, Pergamum Press, Oxford and New York: Author.

International Commission on Radiological Protection (1991). Recommendations of the International Commission on Radiological Protection. Ann ICRP 21:1-3: Author

Livingstone, B.S., Roshan, S., Timothy, P. and Raj, D.V. (2006). Fine tuning of work practices of common Radiological Investigation performs using computed radiograph. Physics of radiograph 13(2): 126132.doi: org/10.1016/j.radi.2005.11.004

Mallam, S.P., Akpa, M.D., Oladipupo, M.D. and Saieid, A (2004). Reappraisal of existing expressions for estimating radiation output from diagnostic x-ray machine. Nigerian Journal of Physics, 16(2): 30-34.

Marija, S.M., Tomislav, M., Ivica, P. and Durya, S. (2008). Importance of quality assurance program implementation in convectional diagnostic radiology. International Journal Collegium Antropologicum. 32(2): $181-184$.

Ogundare, F.O., Uche, C.Z. and Balogun, F.A. (2004). Radiological parameters and radiation doses of patients undergoing abdomen, pelvis and lumbar spine x-ray examination in three Nigerian hospitals. The British Journal of Radiology, 77(923): 934-940.doi: 10.1259/brjr/55841517 
Oluwafisoye,. P.A., Olowookere, C.J., Jibrio, N.N., Bello, T.O., Alausa, S.K. and Efunwde, H.O. (2010). Quality Control and environmental assessment of equipment used in diagnostic radiology. International Journal of Research and Reviews in Applied Sciences, 3(2): 148-158.

Papp, J. (2011). Quality Management in the Imaging Sciences. $4^{\text {th }}$ ed. Jeanne Olson, United State of America.

Rehani, M.M. (1995). Diagnostics Imaging Quality Assurance. $1^{\text {st }}$ Edition India: New Delhi 110002. Jaypee Brothers medical publishers Ltd

United Nations (2000). Sources and Effects of Ionizing Radiation, Report 2000, Vol.1: Sources, Scientific Committee on the Effects of Atomic Radiation (UNSCEAR), UN, New York.

United Nations (2010). Sources and Effects of Ionizing Radiation, Report 2008, Scientific Committee on the Effects of Atomic Radiation (UNSCEAR), UN, New York.

United Nations Scientific Committee on the effects of Atomic Radiation (1993). Sources and effects of ionizing radiation. United Nations, New York: Author.

World Health Organization (1982). Quality Assurance in Diagnostic Radiology. Geneva: Macmillan Procrom: Author. 